\title{
The crisis of biomedical wastes associated with the COVID-19 pandemic and management using sustainable technologies for sound management of healthcare waste associated with pandemics
}

\author{
Udbhav Sharma, Shekhar Kalra, Srishti Gupta, Nirali Seth, Govind Mawari, Naresh Kumar, \\ Mradul Kumar Daga*, M. Meghachandra Singh, Tushar Kant Joshi
}

Centre for Occupational and Environmental Health (COEH), Maulana Azad Medical College, New Delhi, India

Received: 17 November 2021

Revised: 14 January 2022

Accepted: 17 January 2022

*Correspondence:

Dr. Mradul Kumar Daga,

E-mail: drmraduldaga@gmail.com

Copyright: ( $)$ the author(s), publisher and licensee Medip Academy. This is an open-access article distributed under the terms of the Creative Commons Attribution Non-Commercial License, which permits unrestricted non-commercial use, distribution, and reproduction in any medium, provided the original work is properly cited.

\begin{abstract}
The outbreak of coronavirus disease 2019 (COVID-19) wreaked havoc all across the world, claiming numerous casualties. Managing the pandemic has resulted in the production of an unprecedented volume of biomedical waste (BMW), in the form of used personal protective equipment (PPE), diagnostic items, etc. It is a matter of utmost urgency that this BMW is treated, using newer and environmentally sustainable methods as compared to the available ones. The inadequacies of the conventional methods of bio medical waste management call for newer and sustainable alternatives for management like simple greenhouse containers, pyrolysis of polypropylene PPE, usage of silk masks, development of novel biodegradable masks, Antimicrobial Photodynamic therapy (aPDT), nano-photocatalysts, etc. These methods have numerous advantages over currently used methods like incineration, landfilling, etc., and can sustainably be used as an adjunct or an alternative to them.
\end{abstract}

Keywords: Biomedical waste, COVID-19, Sustainable

\section{INTRODUCTION}

COVID-19 disease, caused by a zoonotic novel coronavirus SARS-CoV-2 has spread aggressively throughout the world ever since its outbreak in December 2020. The disease emerged in Wuhan, Hubei Province of the People's Republic of China, and was declared a pandemic by the World Health Organisation (WHO) on 11th March 2020. On January 30th, 2020, India reported its first confirmed case of COVID-19 in General Hospital, Thrissur, Kerala. ${ }^{1}$

The pandemic has affected the citizens and governments of virtually every nation on the planet and has exposed the shortcomings of our public health care system. A major public health concern in consequence to clinical management of COVID-19 patients has been the generation of huge volume of Biomedical Waste (BMW).

With the onset of the pandemic, measures such as the setting up of quarantine camps, use of Personal Protective Equipment (PPE) and frequent use of disinfecting chemicals, research work, and running diagnostic tests were required. WHO estimated a requirement of 89 million medical masks monthly, 76 million and 1.6 million gloves and goggles respectively, for appropriate management of COVID-19, a whopping 40 percent increase. $^{2}$

An increase in the incidence of fungal co-infections like Invasive Mucormycosis (IM), Invasive Candidiasis (IC), Invasive Aspergillosis (IA), and Invasive Cryptococcosis 
(IC) was also seen as a compounding factor of COVID19. These rare but severe infections which resulted in the generation of waste whose infectious hazards and appropriate handling methods were little known to the people dealing with the generated $\mathrm{BMW}^{3}$

If this waste is not treated soundly, it increases the potential for COVID-19 spread. This added burden on the treatment facilities and the overuse of conventional treatment procedures may have significant health and environmental consequences. ${ }^{4}$

The objective of this article is to suggest newer and environmentally sustainable methods of BMW management while emphasizing their merits in the Indian scenario. One of the biggest factors that will decide how speedily the healthcare system gains normalcy after the pandemic, would be the skilful management of the aforementioned quantities of BMW.

\section{DISCUSSION}

\section{Current scenario of $B M W$}

With an exponential increase in COVID-19 cases all over the world, there has been an increased demand for PPE: facemasks, face shields, respirators, and aprons. Essentially, this equipment is single-use, resulting in an excessive amount of BMW generated, especially from hospitals and healthcare centres. Studies have shown that the generation of the amount and type of the BMW is dependent on factors like the number of patients treated daily, the different clinical units, and number of departments in the healthcare facility, the use of reusable items, location of the facility, etc. ${ }^{5}$

At the outbreak of the pandemic in Wuhan, the daily generation of medical waste of COVID-19 patients rose to $2.5 \mathrm{~kg} / \mathrm{bed}$ from the usual daily generation of 0.6 $\mathrm{kg} / \mathrm{bed}$ - a whopping 4-fold increase. ${ }^{6}$ In India, a total of 28747.91 tonnes of BMW was generated between June 2020 and December 2020 which is approximately 135 tonnes per day (TPD). 7

According to the CPCB, the average quantity of COVID19 related BMW generation during June 2021 was about 164 TPD and a total of 198 Common Bio-Medical Waste Treatment Facilities (CBWTF) were engaged in the treatment of said waste.

\section{Hazards associated with the BMW}

Transmission of SARS-CoV-2 has been reported via multiple media solid waste, liquid waste etc. Unsound treatment and management of such BMW pose newer hazards on human life as well as on the progression of the pandemic as a whole.

The virus can make its way into wastewater through sources like stool, vomit, and sputum. There has been confirmed detection of SARS-CoV-2 in untreated water. ${ }^{8}$ Depending on the infection stage, the viral load of SARSCoV-2 in the faces of COVID-positive individuals is in the range of $10^{4}-10^{8}$ copies $/ \mathrm{L}$, which in wastewater gets diluted to $10^{2}-10^{6}$ copies/L. ${ }^{9}$

The risk of viral dissemination via wastewater, with respect to infectivity, has to be assessed.

A study conducted on two surrogate coronaviruses Transmissible Gastroenteritis Virus (TGEV) and Mouse Hepatitis Virus (MHV) showed that the viruses survive and remain infectious for weeks in various water types pasteurized settled sewage, surface water, and reagent grade water. (Casanova et al, 2009) Pumping of wastewater contaminated with SARS-CoV-2 through sewers can lead to aerosolization of the virus, making it a potential source of transmission. This hazard has emphasized the importance of adequate wastewater treatment. ${ }^{11}$

With rising concern over spread through inanimate articles, there is a rise in the usage of chemical disinfectants. The overuse of these disinfectants over such a long period and their disposal into the water bodies without proper treatment can potentially lead to an imbalance of phytoplankton diversity disrupting the aquatic ecosystem. ${ }^{12}$

Diagnostic testing for COVID-19 involves the usage of swabs, reagents, containers, packaging material, safety equipment, etc. which has led to the generation of more than 15000 tonnes of wastes, as of August 2020. ${ }^{13}$

Increased testing is an important step to assess and combat the spread of the virus, but is also leading to the generation of massive amounts of waste. The pandemic necessitated the use of plastics in the form of PPE, face masks, face shields, etc. to ensure protection from the virus. However, the disposal of this protective equipment into the environment leads to the generation of microplastic wastes which might have severe genotoxic potential. ${ }^{14}$

One of the major modalities of dealing with this BMW in developing nations including India is incineration. $50.44 \%$ of total BMW generated in India was YellowCategory BMW (Y-BMW) which is highly infectious and is to be incinerated as per the law of the land. On 27th July 2020, the amount of COVID-19 related Y-BMW crossed India's Y-BMW incineration capacity. BMW incineration results in the emission of several air pollutants and heavy metals such as NOx, CO, SOx, PM, $\mathrm{HCl}, \mathrm{Cd}, \mathrm{Pb}, \mathrm{Hg}, \mathrm{PCBs}, \mathrm{Ni}, \mathrm{Cr}, \mathrm{Be}$, and As which have potential carcinogenic and non-carcinogenic health risks as well as environment-related consequences. ${ }^{15}$

The increasing BMW burden has led to the overuse of the incineration units in the country and increased generation and release of aforementioned hazardous gases and 
metals into the environment. Owing to the ability of the pollutants to affect the respiratory system, there is a significant association between the increased concentrations of air pollutants and the surging rate of COVID-19 associated mortality. ${ }^{16}$

\section{Current Guidelines for handling of BMW}

Tonnes of hospital waste like anatomical waste such as body parts, organs, tissues, blood, and body fluids along with soiled linen, syringe, needles, plaster casts, etc are produced every day. BMW management activities are monitored by the CPCB.

The CPCB has given the following guidelines for healthcare facilities having isolation wards for COVID-19 patients to ensure safe handling and disposal of BMW generated during treatment.

Separate records of waste generated from COVID-19 isolation wards must be maintained. Separate color-coded bins/bags/containers are kept to maintain proper segregation of waste. COVID-19 waste is to be collected separately in double bags and labelled as 'COVID-19 Waste' before handing over to CBWTF; this marking would help in priority treatment and immediate disposal of this waste. The inner and outer surface of containers/bins/trolleys used for storage of COVID- 19 waste should be disinfected with one percent sodium hypochlorite solution daily. To minimize waste generation, non-disposable items must be used for serving food; if the use of disposable items is inevitable, use biodegradable cutlery. Collect used PPEs such as goggles, face shield, splash-proof apron, plastic coverall, and hazmat suit into Red Bag. Only the used masks, gloves, tissues, or swabs contaminated with blood or body fluids of COVID 19 patients should be treated as BMW and collected in yellow bags. Left-over food items, empty juice bottles, water bottles, and any other items, generated or handled by COVID-19 patients should be collected with other general solid waste in bags, securely tied for handing over to waste collectors. Yellow-coloured bags should not be used for general solid waste. Masks and gloves used by persons other than COVID-19 patients should be kept in a paper bag for a minimum of 72 hours prior to disposal as general waste.

\section{Existing conventional methods}

The most commonly used conventional methods of waste disinfection and their salient features are summarised in Table 1.

\section{Sustainable alternative methods of management}

\section{Use of Greenhouse effect for waste decontamination}

As an effective alternative to expensive methods of waste treatment, solar radiation can also be utilized, especially instrumental in developing countries. A simple acrylic container can be used to accumulate solar radiation using the greenhouse effect.

When the ambient temperature is above $30^{\circ} \mathrm{C}$, a temperature above $40{ }^{\circ} \mathrm{C}$ can be achieved, at which most of the viruses reach below detection levels, within 90 minutes. Even in temperatures as low as $20{ }^{\circ} \mathrm{C}$, viruses are deactivated within a maximum of 3 hours. ${ }^{17}$

The acrylic containers used in this method can be manufactured for less than $30 \$$. India is a tropical country with an abundance of solar radiation (average annual temperature of $25.78^{\circ} \mathrm{C}$ ). The cost-effectiveness of the bins and the high temperatures of the Indian subcontinent make it an extremely viable option to deal with the massive amounts of infectious waste being generated during the pandemic. This method is especially effective for biological decontamination of PPEs which can then be dealt with as non-infectious waste. This would greatly reduce the burden on incineration facilities, reduce emissions, and make the wastes much safer to deal with.

\section{Pyrolysis}

With the evident increase in polypropylene (PP)-based PPE, there has been a rise in the accumulation of plastic waste. This can be dealt with using the process of pyrolysis. Pyrolysis involves heating polymers, in the absence of oxygen at increased pressure and temperatures around $500{ }^{\circ} \mathrm{C}$, leading to depolymerization into smaller molecules. Pyrolysis of plastics, as in PP-based PPE, is instrumental in generating energy source in the form of liquid oil, gaseous fuel, and solid char which can be used in fuel-based applications. This process may prove beneficial in minimizing the waste, which would otherwise be incinerated or accumulated in landfills. ${ }^{18,19}$

\section{Steril wave}

Bertin Technologies, a subsidiary of Constructions industrielles de la Méditerranée (CNIM) a French equipment manufacturer and industrial contractor, manufactures STERILWAVE technology. STERILWAVE is based on a shredding system with a microwave mobile which is used to sterilize solid BMW into municipal waste without producing any liquid affluents. Microwave technology allows sterilization without the use of a saturated stream and water, resulting in a stable and dry waste that can be used as Refusederived fuel. Approved by the French Ministry of Health in 2012, Sterilwave-440 claims to treat BMW at a rate of $88 \mathrm{~kg} /$ hour. $^{20}$

In the handling of BMW in the pandemic, this technology has shown promise in China where it is being used as a mobile facility. ${ }^{21}$

\section{Silk masks as an alternative to plastic-based masks}

Silk is a natural material secreted by silk moth caterpillars (Bombyx mori, Hyalophora cecropia) to make their 
cocoons. Silk may be used to make PPE and face masks due to its inherent hydrophobic property which prevents the penetration and absorption of droplets that cause the transmission of SARS-CoV-2.

Table 1: Conventional methods of waste disinfection and their salient features.

\begin{tabular}{|c|c|c|c|c|}
\hline $\begin{array}{l}\text { Disinfection } \\
\text { technology }\end{array}$ & Principle & Waste Treated & Advantages & Disadvantages \\
\hline Incinerators & $\begin{array}{l}\text { High temperature } \\
\text { thermal process ( } 800 \mathrm{C} \\
\text { to } 1200 \mathrm{C}) \text {, under } \\
\text { controlled conditions, } \\
\text { killing the pathogen. }\end{array}$ & $\begin{array}{l}\text { Most of the COVID } \\
\text { Waste }>1100^{\circ} \mathrm{C} \\
\text { All hospital waste, } \\
\text { (Anatomical Waste, } \\
\text { Infectious Waste, } \\
\text { Medicinal Waste, } \\
\text { Chemical Waste, } \\
\text { Sharps) }>800^{\circ} \mathrm{C}\end{array}$ & $\begin{array}{l}\text { Simple technique, } \\
\text { causes destruction of } \\
\text { BMW/ COVID } \\
\text { waste. } \\
\text { Waste Volume } \\
\text { reduce by } 90 \%\end{array}$ & $\begin{array}{l}\text { High construction cost, } \\
\text { Energy-intensive } \\
\text { Produces ash that contains } \\
\text { leached metals, dioxins } \\
\text { and furans }\end{array}$ \\
\hline Autoclave & $\begin{array}{l}\text { Thermal high frequency } \\
\text { process at low } \\
\text { temperature }\left(121^{\circ} \mathrm{C}\right) \\
\text { Waste is subjected to } \\
\text { high pressure steam } \\
\text { which penetrates the } \\
\text { waste material and kills } \\
\text { the microorganism }\end{array}$ & $\begin{array}{l}\text { Microbiology Waste } \\
\text { Biotechnology Waste } \\
\text { Waste Sharps } \\
\text { Soiled Waste } \\
\text { Solid Waste } \\
\text { Contaminated Waste }\end{array}$ & $\begin{array}{l}\text { Low operating costs } \\
\text { Facilitates recycling } \\
\text { of plastics } \\
\text { Environment } \\
\text { Friendly } \\
\text { Familiar to healthcare } \\
\text { staff }\end{array}$ & $\begin{array}{l}\text { High installation costs } \\
\text { No reduction in weight of } \\
\text { waste } \\
\text { Unpleasant odour } \\
\text { Slow }\end{array}$ \\
\hline $\begin{array}{l}\text { Chemical } \\
\text { disinfectants }\end{array}$ & $\begin{array}{l}1 \% \text { bleach (sodium } \\
\text { hypochlorite) solution or } \\
\text { diluted active chlorine } \\
\text { solution }(0.5 \%) \text { is used. } \\
\text { Electronegativity of } \\
\text { chlorine helps in } \\
\text { oxidizing peptide links } \\
\text { and denaturing proteins } \\
\text { that follows penetration } \\
\text { of cell layers even at } \\
\text { neutral pH. }\end{array}$ & $\begin{array}{l}\text { Liquid infectious } \\
\text { waste (blood, urine, } \\
\text { faeces, hospital } \\
\text { sewage) Infectious } \\
\text { Waste } \\
\text { Solid medical waste } \\
\text { after shredding }\end{array}$ & $\begin{array}{l}\text { Cheap } \\
\text { Widely available } \\
\text { Easy to use for } \\
\text { domestic purposes }\end{array}$ & $\begin{array}{l}\text { Chemicals used are } \\
\text { dangerous } \\
\text { No waste volume } \\
\text { reduction } \\
\text { Aerosols formed can } \\
\text { penetrate alveoli on } \\
\text { inhalation } \\
\text { Risk of cancer due to } \\
\text { absorbance of atomised } \\
\text { disinfectants into skin }\end{array}$ \\
\hline $\begin{array}{l}\text { Vaporized } \\
\text { Hydrogen } \\
\text { Peroxide }\end{array}$ & $\begin{array}{l}\text { Liquid } \mathrm{H} 2 \mathrm{O} 2 \text { converted } \\
\text { to vapor which fills the } \\
\text { chamber, contacts all } \\
\text { surfaces and penetrates } \\
\text { lumen. }\end{array}$ & $\begin{array}{l}\text { Reusable metal and } \\
\text { non-metal devices } \\
\text { Medical instruments }\end{array}$ & $\begin{array}{l}\text { Items can be } \\
\text { reprocessed and } \\
\text { reused after } \\
\text { disinfection } \\
\text { Low temperature } \\
\text { Environment safe by- } \\
\text { products (water and } \\
\text { oxygen) }\end{array}$ & $\begin{array}{l}\text { Incompatibility with } \\
\text { cellulose and nylon } \\
\text { Health problems related to } \\
\text { skin, mucosa and alveoli } \\
\text { due to atomised particles } \\
\text { produced during fogging }\end{array}$ \\
\hline
\end{tabular}

In addition, silk has antibacterial and antiviral properties. Silk masks are breathable and remain thin and comfortable. Four layers of silk have $86 \pm 5 \%$ filtration efficiency (FE) for particles $<300 \mathrm{~nm}$ and an $88 \pm 1 \%$ filtration efficiency for particles $>300 \mathrm{~nm}$. A silk/cotton hybrid mask has a FE of $94 \pm 2 \%$ for particles $<300 \mathrm{~nm}$ and a $98.5 \pm 0.2 \%$ FE for particles $>300 \mathrm{~nm}$ compared to an N95 mask with a FE of $85 \pm 15 \%$ for particles $<300 \mathrm{~nm}$ and a $99.9 \pm 0.1 \%$ FE for particles $>300 \mathrm{~nm} .^{22,23}$

India is one of the largest producers of silk in the world. ${ }^{24}$ The silk industry has faced a crisis during the COVID-19 pandemic, the use of silk for the production of protective gear may act as a boost to the textile industry while providing an effective and environment friendly alternative to the N95 masks.

\section{Reusable PPE}

Single-use PPE is not a sustainable practice and new research since the beginning of the current pandemic indicates that PPE disinfection and reuse is possible on a large scale through methods such as hydrogen peroxide vapor, ultraviolet or gamma-irradiation, ethylene oxide gasification, application of spray-on disinfectants, and infusion of base material with antimicrobial nanoparticles. The material must be calibrated such that during each disinfection cycle it does not compromise the primary function of PPEs. The focus on reducing, reusing, and recycling resources should guide policy development for PPE management during and after the current pandemic. ${ }^{25}$ 


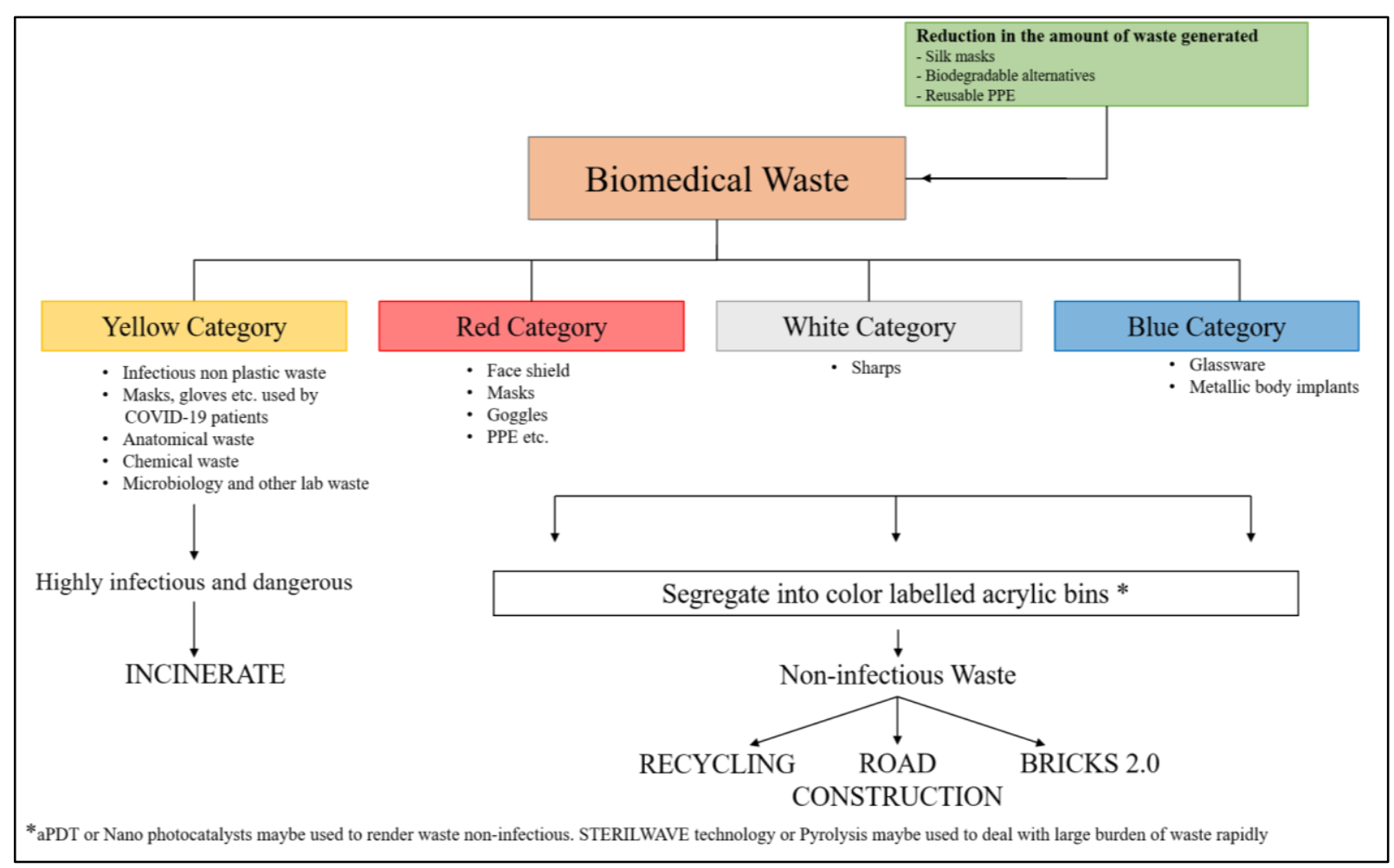

Figure 1: Algorithm for treatment of COVID-19 related waste.

\section{Biodegradable masks}

Active research is being conducted throughout to tackle the issue of shortage of PPE while minimizing waste generation.

Researchers at the University of British Columbia have designed the world's first fully compostable and biodegradable medical mask, as an alternative to the conventionally used synthetic masks. After necessary testing, the prototypes will be up for certification. ${ }^{26}$

\section{Recycling PPE and facemasks into bricks}

Brick 2.0, an innovation by a Gujarat-based company, Eco-Eclectic Technologies, aimed at dealing with increased waste from PPE and facemasks by recycling the material to create bricks for construction. After disinfecting the equipment, prototype experiments were conducted to explore the ideal combination of materials. The successful ratio of $52 \%$ PPE $+45 \%$ paper waste + $3 \%$ binder was identified for these bricks. Compared to autoclaved aerated concrete (AAC) blocks and red bricks,Brick 2.0 was found to be much more durable, making it three times stronger than conventional bricks, at twice the size and half the price. ${ }^{27}$

\section{Antimicrobial photodynamic therapy (aPDT)}

aPDT has the potential to be instrumental in treating COVID-associated BMW. The process uses common photosensitizers like methylene blue (MB) or porphyrins and results in antimicrobial inactivation on exposure to low-power lasers. While preventing infections, it can help in developing photoactive fabrics (masks, suits) to disinfect surfaces. aPDT has shown promising results on inactivation of enveloped viruses, like SARS-CoV-2. ${ }^{28}$

\section{Nanophotocatalysts}

Photocatalysis is a series of chemical reactions that are initiated by electromagnetic irradiation. Photocatalysts are superior to conventional techniques such as chlorination, as they do not generate harmful and undesirable by-products. Photocatalytic surfaces can also be used because of their self-sanitizing properties. The overall cost of photodegradation for the decontamination and disinfection of waste is lower, due to the low energy consumption and accessibility to solar energy. Advantages of photocatalysis include: a better alternative to the traditional treatment techniques with the capability of using solar energy and formation of harmless byproducts unlike the other methods wherein pollutants only transfer from one form to another. Nanoparticles are used owing to their inherent ability to inactivate viruses, bacteria, fungi, and yeasts, through photothermal or photocatalysis induced reactive oxygen species. ${ }^{29}$

\section{CONCLUSION}

The pandemic has led to the generation of huge volume of BMW whose infectious potential and appropriate handling methods were largely unknown to people dealing with the management of these wastes. The safest 
approach for protection from the virus was the use of plastic-based protective equipment and disposal of wastes by incineration. However, these practices have taken a toll on the environment and human health and thus, are not sustainable in the long term. With the passage of time, research has been conducted around sustainable and innovative ways of dealing with the BMW. Greenhouse effect, aPDT, STERILWAVE and Nano-photocatalyst technology for waste management, reuse of PPE after disinfection, conversion of PPE into fuel or construction material and replacement of plastic-based masks with environment-friendly silk masks are some of the ways to minimise the hazards of BMW.

\section{Recommendations}

Figure 1 represents an algorithm which suggests how these sustainable alternatives can be incorporated into our existing waste disposal and treatment system to reduce the harmful effects of BMW on the environment while also maintaining adequate safety standards.

\section{Funding: No funding sources \\ Conflict of interest: None declared \\ Ethical approval: Not required}

\section{REFERENCES}

1. Andrews MA, Areekal B, Rajesh KR, Krishnan J, Suryakala R, Krishnan B et al. First confirmed case of COVID-19 infection in India: A case report. The Indian Journal of Medical Research. 2020;151(5):490-2.

2. WHO (2020). Shortage of personal protective equipment endangering health workers worldwide. Available at: https://www.who.int/news/item/03-032020-shortage-of-personal-protective-equipmentendangering-health-workers-worldwide. Accessed on 11 September, 2021.

3. Bhatt K, Agolli A, Patel MH, Garimella R, Devi M, Garcia E et al. High mortality co-infections of COVID-19 patients: Mucormycosis and other fungal infections. Discoveries. 2020;9(1):e126.

4. Nzediegwu C, Chang SX. Improper solid waste management increases potential for COVID-19 spread in developing countries. Resources, Conservation, and Recycling. 2020;161:104947.

5. Bdour A, Altrabsheh B. Hadadin N, Al-Shareif M. Assessment of medical wastes management practice: A case study of the northern part of Jordan. Waste Management (New York, N.Y.). 2007;27(6):746-59.

6. Yu H, Sun X, Solvang WD, Zhao X. Reverse Logistics Network Design for Effective Management of Medical Waste in Epidemic Outbreaks: Insights from the Coronavirus Disease 2019 (COVID-19) Outbreak in Wuhan (China). International Journal of Environmental Research and Public Health. 2019;17(5):1770.
7. Chand S, Shastry CS, Hiremath S, Joel JJ, Krishnabhat $\mathrm{CH}$, Mateti UV. Updates on biomedical waste management during COVID-19: The Indian scenario. Clinical Epidemiology and Global Health. 2020;11:100715.

8. Ahmed W Angel N, Edson J, Bibby K, Bivins A, O'Brien JW et al. First confirmed detection of SARS-CoV-2 in untreated wastewater in Australia: A proof of concept for the wastewater surveillance of COVID-19 in the community. The Science of the Total Environment. 2020;728:138764.

9. Saawarn B, Hait S. Occurrence, fate and removal of SARS-CoV-2 in wastewater: Current knowledge and future perspectives. Journal of Environmental Chemical Engineering. 2021;9(1):104870.

10. Casanova L, Rutala WA, Weber DJ, Sobsey MD. Survival of surrogate coronaviruses in water. Water Research. 2009;43(7):1893-8.

11. Gormley M, Aspray TJ, Kelly DA. COVID-19: Mitigating transmission via wastewater plumbing systems. The Lancet. Global Health. 2020;8(5):e643.

12. Islam SMD, Huda ME. Water Pollution by Industrial Effluent and Phytoplankton Diversity of Shitalakhya River, Bangladesh. Journal of Scientific Research. 2016;8(2):191-8.

13. Celis JE, Espejo W, Paredes-Osses E, Contreras SA, Chiang G, Bahamonde P. Plastic residues produced with confirmatory testing for COVID-19: Classification, quantification, fate, and impacts on human health. The Science of the Total Environment. 2021;760:144167.

14. Tagorti G, Kaya B. Genotoxic effect of microplastics and COVID-19: The hidden threat. Chemosphere. 2022;286:131898.

15. Thind PS, Sareen A, Singh DD, Singh S, John S. Compromising situation of India's bio-medical waste incineration units during pandemic outbreak of COVID-19: Associated environmental-health impacts and mitigation measures. Environmental Pollution (Barking, Essex: 1987). 2021;276:116621.

16. Zhu Y, Xie J, Huang F, Cao L. Association between short-term exposure to air pollution and COVID-19 infection: Evidence from China. The Science of the Total Environment. 2020;727:138704.

17. Maher OA, Kamal SA, Newir A, Persson KM. Utilization of greenhouse effect for the treatment of COVID-19 contaminated disposable waste-A simple technology for developing countries. International Journal of Hygiene and Environmental Health. 2021;232:113690.

18. Harussani MM, Sapuan SM, Rashid U, Khalina A, Ilyas RA. Pyrolysis of polypropylene plastic waste into carbonaceous char: Priority of plastic waste management amidst COVID-19 pandemic. Science of The Total Environment. 2022;803:149911.

19. Vijayakumar A, Sebastian J. Pyrolysis process to produce fuel from different types of plastic - a review. IOP Conference Series: Materials Science and Engineering. 2018;396:012062. 
20. Medical waste disposal equipment (n.d.). Bertin Medical Waste. Available at: https://www.bertinmedical-waste.com/products/biohazardous-wastemanagement-systems/sterilwave-440/. Accessed on 12 September 2021.

21. Resilient Environmental Solutions, 2020. Environmental Assessment for the Proposed Establishment of STERILWAVE Apparatus for Treatment of Medical Waste at Rhino Park Private Hospital, Windhoek Screening Report. Available at: http://www.eia.met.gov.na/screening/1371_a_screen ing_report_rhinopark_hospital_sterilwave.pdf.

Accessed on 12 September 2021.

22. Konda A, Prakash A, Moss GA, Schmoldt M, Grant GD, Guha S. Aerosol Filtration Efficiency of Common Fabrics Used in Respiratory Cloth Masks. ACS Nano. 2020; acsnano.0c03252.

23. Parlin AF Stratton SM, Culley TM, Guerra PA. A laboratory-based study examining the properties of silk fabric to evaluate its potential as a protective barrier for personal protective equipment and as a functional material for face coverings during the COVID-19 pandemic. PLoS ONE. 2020;15(9):e0239531.

24. Ravikumar A. Indian silk industry in the global scenario. 2011;1:100-10.

25. Singh N, Tang Y, Ogunseitan OA. Environmentally Sustainable Management of Used Personal
Protective Equipment. Environmental Science \& Technology. 2020; acs.est.0c03022.

26. UBC researchers develop biodegradable medical mask for COVID-19. Available at: https://news.ubc.ca/2020/05/21/ubc-researchersdevelop-biodegradable-medical-mask-for-covid-19/. Accessed on 12 September 2021.

27. Adlakha N. India's 'Recycle Man' makes bricks from discarded face masks. The Hindu. Available at: https://www.thehindu.com/life-and-style/homesand-gardens/binish-desai-has-designed-bricks-madefrom-recycled-face-masks-during-covid-19/art icle32295016.ece. Accessed on 7 August, 2020.

28. Almeida A, Faustino MAF, Neves MG. Antimicrobial Photodynamic Therapy in the Control of COVID-19. Antibiotics (Basel, Switzerland). 2020;9(6):E320.

29. Hooshmand S, Kargozar S, Ghorbani A, Darroudi M, Keshavarz M, Baino F et al. Biomedical Waste Management by Using Nanophotocatalysts: The Need for New Options. Materials. 2020;13(16):3511.

Cite this article as: Sharma U, Kalra S, Gupta S, Seth N, Mawari G, Kumar N et al. The crisis of biomedical wastes associated with the COVID-19 pandemic and management using sustainable technologies for sound management of healthcare waste associated with pandemics. Int J Community Med Public Health 2022;9:1084-90. 